\title{
THE LEGAL ASPECTS OF PREVENTING THE SPREAD OF THE CORONAVIRUS INFECTION IN THE RUSSIAN FEDERATION: THE LEGISLATIVE NOVELTIES AND THEIR FEATURES
}

\author{
Alexander V. Sarychev \\ Belgorod Law Institute of the Ministry of Internal Affairs of Russia named after I.D. Putilin, \\ Belgorod, Russian Federation \\ Ivan N. Arkhiptsev \\ Belgorod Law Institute of the Ministry of Internal Affairs of Russia named after I.D. Putilin, \\ Belgorod, Russian Federation \\ Ekaterina A. Karaulova \\ Belgorod Law Institute of the Ministry of Internal Affairs of Russia named after I.D. Putilin, \\ Belgorod, Russian Federation
}

Introduction: currently, worldwide and in the Russian Federation, one of the most pressing problems is the fight against the new coronavirus infection COVID-19, which was assigned the status of a pandemic by the World Health Organization in early 2020. The huge economic damage to the countries directly affected by the pandemic and the global economy as a whole, fatalities, abandoning business, increase in unemployment, the restructuring of the economy to work in a new environment are a certain list of consequences we have been faced with in recent times due to the spread of COVID-19. The purpose of the study is to analyze the legislation aimed at supporting the economy and the population during the spread of the pandemic, as well as the measures of administrative and criminal responsibility in the domestic legislation aimed at preventing the spread of the coronavirus infection, as well as to examine the features of their application. Methods: the methodological framework for the research consists of the general scientific methods of cognition: the ascent from the abstract to the concrete, the hypotheticaldeductive, axiomatic and formalization methods, as well as the interrelated methods: analysis, synthesis. The results of the study and conclusions: the authors consider the changes in the legislation of the Russian Federation aimed at overcoming the consequences, as well as the fight against the coronavirus infection.

Key words: coronavirus, pandemic, sanitary and epidemiological measures, prevention of the spread of the coronavirus, administrative responsibility, criminal punishment.

Citation. Sarychev A.V., Arkhiptsev I.N., Karaulova E.A. The Legal Aspects of Preventing the Spread of the Coronavirus Infection in the Russian Federation: The Legislative Novelties and Their Features. Legal Concept $=$ Pravovaya paradigma, 2021, vol. 20, no. 1, pp. 27-38. (in Russian). DOI: https://doi.org/10.15688/lc.jvolsu.2021.1.4

\section{ПРАВОВЫЕ АСПЕКТЫ ПРЕДУПРЕЖДЕНИЯ РАСПРОСТРАНЕНИЯ КОРОНАВИРУСНОЙ ИНФЕКЦИИ В РОССИЙСКОЙ ФЕДЕРАЦИИ: НОВЕЛЛЫ ЗАКОНОДАТЕЛЬСТВА И ИХ ОСОБЕННОСТИ}

\author{
Александр Викторович Сарычев \\ Белгородский юридический институт МВД России им. И.Д. Путилина, \\ г. Белгород, Российская Федерация
}


Иван Николаевич Архипцев

Белгородский юридический институт МВД России им. И.Д. Путилина, г. Белгород, Российская Федерация

\title{
Екатерина Алексеевна Караулова
}

Белгородский юридический институт МВД России им. И.Д. Путилина, г. Белгород, Российская Федерация

\begin{abstract}
Введение: в настоящее время во всем мире и в Российской Федерации одной из самых актуальных проблем является борьба с новой коронавирусной инфекцией COVID-19, которой в начале 2020 г. Bceмирной организацией здравоохранения был присвоен статус пандемии. Огромный экономический ущерб странам, как непосредственно пострадавшим от пандемии, так и глобальной экономике в целом, безвозвратные потери населения, закрытие производств, повышение безработицы среди населения, перестройка экономики на работу в новых условиях - лишь некоторый перечень последствий, с которыми мы столкнулись в последнее время из-за распространения COVID-19. Цель исследования: проанализировать законодательство, направленное на поддержку экономики и населения в период распространение пандемии, а также меры административной и уголовной ответственности в отечественном законодательстве, направленные на предупреждение распространения коронавирусной инфекции, а также рассмотреть особенности их применения. Методы исследования: методологическую основу данного исследования составляют общенаучные методы познания: восхождение от абстрактного к конкретному, гипотетико-дедуктивный, аксиоматический и метод формализации, а также взаимосвязанных методов: анализа, синтеза. Результаты исследования и выводы: авторами рассмотрены изменения в законодательстве Российской Федерации, направленные на преодоление последствий, а также борьбу с коронавирусной инфекцией.
\end{abstract}

Ключевые слова: коронавирус, пандемия, санитарно-эпидемиологические меры, предупреждение распространения коронавируса, административная ответственность, уголовное наказание.

Цитирование. Сарычев А. В., Архипцев И. Н., Караулова Е. А. Правовые аспекты предупреждения распространения коронавирусной инфекции в Российской Федерации: новеллы законодательства и их особенности // Legal Concept = Правовая парадигма. -2021 . - T. 20, № 1 - - C. 27-38. - DOI: https://doi.org/ 10.15688/lc.jvolsu.2021.1.4

\section{Введение}

Как известно, и не для кого уже не секрет то обстоятельство, что за 2020 г. жизнь практически большинства стран мира кардинально изменилась. Размеренная, привычная жизнь людей была приостановлена, а вызвано это распространением особо опасного виpyca COVID-19. Сейчас практически трудно о чем-то говорить, кроме нового коронавируса, центральное и местное телевидение, все сайты сети Интернет, реклама в СМИ, баннеры на улицах, предупредительные листы в (на) магазинах, аптеках предупреждают о распространении пандемии. Огромный урон нанесен экономике государств, индивидуальные предприниматели, малый и средний бизнес находятся в тяжелом положении. Так, согласно данным распространения коронавируса, размещенных в Интернете, по состоянию на 31 января 2021 г. в мире было зафиксировано
103138668 случаев заражения коронавирусом COVID-19. Общее число смертей от коронавирусной инфекции в мире составляет 2229505 человек. Уровень летальности: $2,16 \%$. Подтвержденных случаев полного излечения от вируса в мире: 74773745 [3]. Согласно мнению экспертов, снижение российской экономики в 2020 г. составит $3,6 \%$, в то время как мировая экономика снизится на 4,4\%. Падение реальных располагаемых доходов населения РФ за 9 месяцев 2020 г. превысило $4 \%$, а уровень бедности во II квартале вырос до 13,5 \% с 12,7 \% во II квартале 2019 года [21].

Рестораны, парикмахерские, турагентства, зубоврачебные клиники и многие, многие другие сферы бизнеса временно не работают. И сколько еще продлится пандемия, увы, никто не знает. Работники уволены, несмотря на обращения главы государства о сохранении рабочего места и заработной пла- 
ты. В настоящее время российские суды стали давать оценку действиям работодателей, незаконно уволивших работников в период пандемии COVID-19 [14].

В первую волну распространения коронавирусной инфекции многие вузы, школы, садики так же были вынуждены закрыться. В связи с тем, что современные компьютерные телекоммуникации способны обеспечить передачу знаний и доступ к разнообразной учебной информации наравне, а иногда и гораздо эффективнее, чем традиционные средства обучения, то власти вынуждены были ввести новые меры, а именно проведение занятий путем дистанционного обучения.

В сфере здравоохранения также произошли существенные изменения. Так было принято постановление главного санитарного врача России от 22 мая 2020 г. № 15, которое установило требования к комплексу организационных, профилактических, санитарно-противоэпидемических мероприятий, проведение которых обеспечивает предупреждение возникновения и распространения случаев заболевания новой коронавирусной инфекцией (COVID-19) на территории Российской Федерации [8].

Так что же представляет под собой COVID-19? Коронавирусы представляют собой оболочечные вирусы, содержащие одноцепочечную РНК положительной полярности, относятся к порядку Nidovirales, семейству Coronaviridae, которое включает 2 подсемейства - Orthocoronavirinae и Letovirinae [20, c. 54$]$.

\section{1. Меры по поддержке экономики, бизнеса и граждан}

В связи с представленными изменениями государство приняло ряд мер по поддержанию жизнедеятельности населения. Одной из таких мер является введение кредитных каникул. Сущность данных каникул заключается в возможности временно не платить выплаты по кредитам и займам, при этом начисление неустойки происходить не будет, а также не будет ухудшаться кредитная история клиента. Такие кредитные каникулы могут продлиться полгода, как отметил Президент Рос- сийской Федерации: «Если у лица резко сократился его месячный доход, более чем на 30 процентов, в этом случае использование кредитных каникул будет оправдано». Но снижение своего месячного дохода необходимо подтвердить необходимыми документами, и представить их нужно в течение 90 дней с момента подачи заявления [18].

Согласно Постановлению Правительства Российской Федерации от 2 апреля 2020 г. № 420, которое в последующем продлевалось постановлениями Правительства РФ, до 1 января 2021 г. не будут начисляться пени и штрафы за несвоевременное внесение оплаты за жилое помещение и коммунальные услуги, а также взносов на капитальный ремонт [9]. Также одной из мер поддержки населения стали моратории на взносы на капитальный ремонт многоквартирных домов в ряде российских регионов [2].

Государство предприняло меры по поддержанию населения в сфере предоставлений пособий по безработице. Так, если до распространения короновирусной инфекции максимальный размер пособия был в размере 8 тыс. рублей, то сейчас эта сумма увеличена до 12130 рублей - действующего размера федерального МРОТ. Кроме этого, Правительство предоставляет выплаты следующим категориям безработных:

- кто имеет регистрацию по месту жительства (постоянную) в данном регионе;

- отработал не менее 60 дней в 2020 году [7].

В сфере предоставления налоговой отчетности так же были внесены изменения. В частности, был продлен срок сдачи физическими лицами декларации на 3 месяца, до 30 июля 2020 года [10].

Говоря о поддержке семей с детьми, следует отметить, что в этом направлении государством также были предприняты существенные шаги. Например, были увеличены выплаты пособий по уходу за ребенком (в 2 раза); семьям, имеющим детей в возрасте до трех лет, были предоставлены выплаты в размере 5000 руб. на каждого ребенка; производились выплаты по материнскому капиталу лицам, имеющим на него право, до 1 июля 2020 г., даже если он уже был выплачен ранее. Кроме этого, на каждого ребенка 
возрастом от 3 до 16 лет было выделено по 10 тыс. руб. в качестве единовременной помощи [15].

Говоря о поддержке бизнеса, следует указать, что то на сайте ФНС России создан специальный раздел, где опубликована вся информация о мерах поддержки в условиях короновируса [5]. Так, на рисунке 1 приведены все меры поддержки индивидуальных предпринимателей.

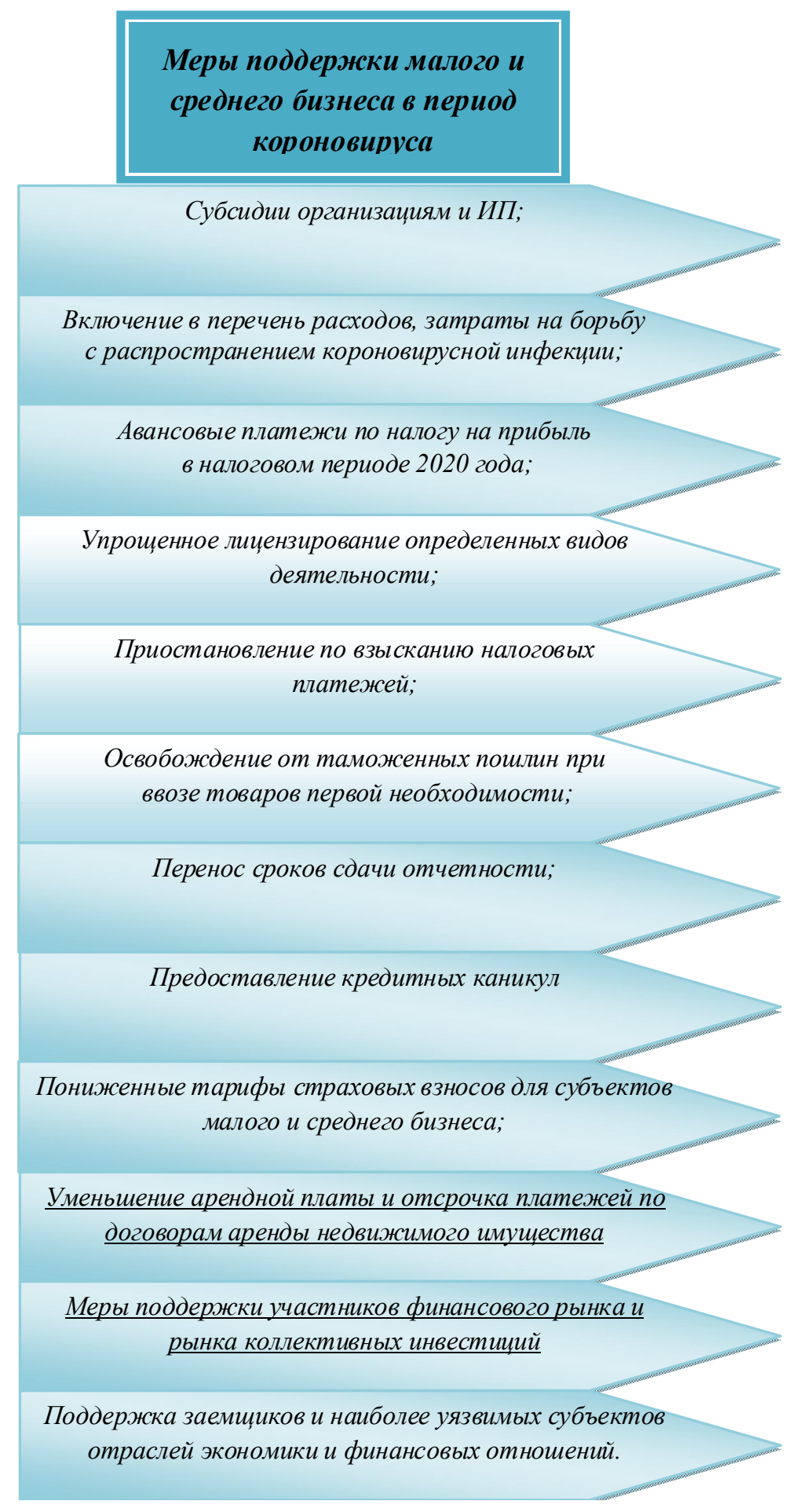

Рис. 1. Меры поддержки предпринимательства в период короновируса 


\section{2. Изменения в административное} и уголовное законодательство

Важными также стали изменения, внесенные законодателем в административное и уголовное законодательство.

1 апреля 2020 г. в КоАП были внесены изменения Федеральным законом № 99 [17]. В частности, изменения внесены в ст. 6.3 КоАП РФ, санкция данной нормы предполагает штраф для конкретных категорий лиц (рис. 2).

Кроме этого, в гл. 20 КоАП РФ была включена новая ст. 20.6.1. Она устанавливает административную ответственность за нарушение режима самоизоляции во время пандемии. А именно это касается в части не- выполнения правил поведения при введении режима повышенной готовности на территории, на которой существует угроза возникновения чрезвычайной ситуации, или в зоне чрезвычайной ситуации. Административная ответственность по указанной статье наступит в случае, если противоправные действия не подпадут под санкцию ст. 6.3 КоАП РФ.

Поправки внесены и в ст. 13.15 КоАП РФ. Так, для юридических лиц за распространение в СМИ или информационно-телекоммуникационных сетях под видом достоверных сообщений заведомо недостоверной информации об обстоятельствах, представляющих угрозу жизни и безопасности граждан, и (или) о принимаемых мерах по обеспечению безопасности населения и территорий, приемах и

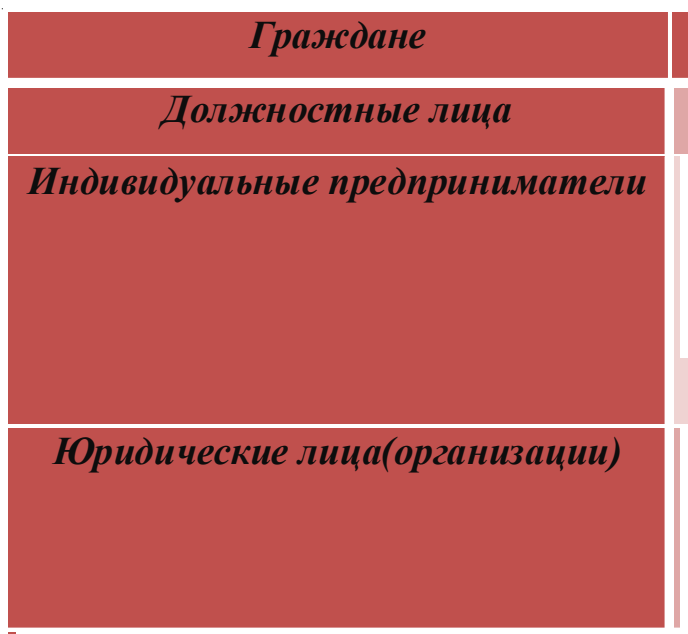

от 15 mыс. до 40 mыс. руб.
от 50 mыс. до 150 mыс. руб.
от 50 mыс. до 150 mыс. руб. или

\section{приостановление деятельности на} срок до 90 суток

\section{от 200 тыс. до 500 тыс. руб. или \\ приостановление деятельности на срок до 90 суток}

Если нарушения повлекли причинение вреда или смерть человека:

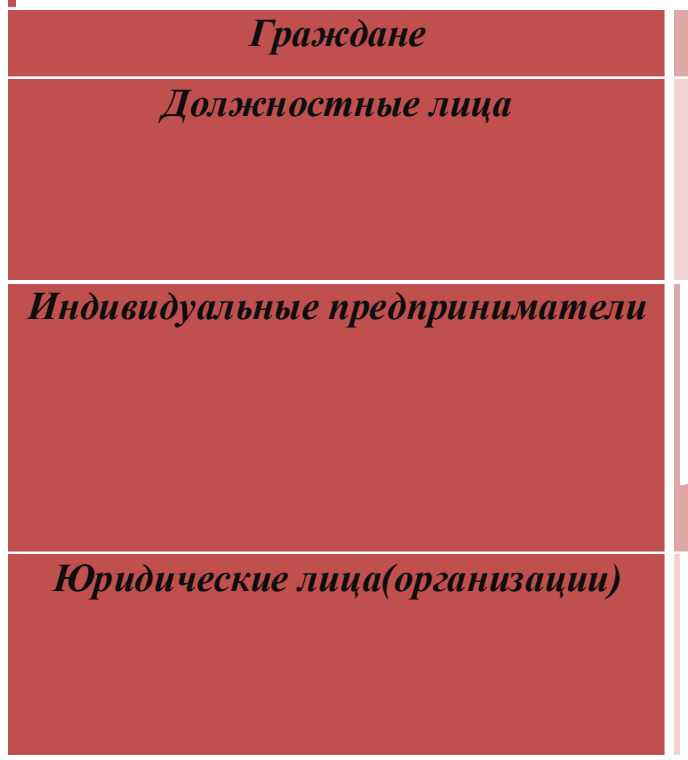

от 150 тыс. до 300 тыс. руб.
от 300 тыс. до 500 тыс. руб. или
дисквалификация на срок от одного
года до трех лет
от 500 тыс. до 1 млн. руб. или
приостановление деятельности на
срок до 90 суток
от 500 тыс. до 1 млн. руб. или
приостановление деятельности на
срок до 90 суток

Рис. 2. Штраф для конкретных категорий лиц, за нарушение ст. 6.3 КоАП РФ 
способах защиты от указанных обстоятельств, предусмотрен штраф в размере от 1,5 до 3 млн руб. с конфискацией предмета административного правонарушения. В случаях, когда данные действия повлекли смерть человека, причинение вреда здоровью человека или имуществу, массовое нарушение общественного порядка и (или) общественной безопасности, прекращение функционирования объектов жизнеобеспечения, транспортной или социальной инфраструктуры, кредитных организаций, объектов энергетики, промышленности или связи - штраф будет варьироваться в пределах от 3 до 5 млн рублей. Для того чтобы уточнить, подпадает ли данное обстоятельство под обстоятельство, представляющие угрозу для жизни здоровью или имуществу, необходимо обратиться к примечанию данной статьи, в котором указывается, что таковыми являются обстоятельства ЧС природного, техногенного, в том числе экологического характера, эпидемии, эпизоотии, аварии, катастрофы и т. д. Изменения в вышеуказанные статьи КоАП РФ вступили в силу с 1 апреля 2020 года.
За нарушение санитарно-эпидемиологических правил действующим законодательством предусмотрена и уголовная ответственность (см. рис. 3).

Так, Уголовный кодекс был дополнен ст. 207.1, которая предполагает ответственность за распространение ложной информации об обстоятельствах, которые представляют угрозу жизни и безопасности граждан. Таковыми обстоятельствами являются чрезвычайные ситуации природного и техногенного характера, чрезвычайные экологические ситуации, в том числе эпидемии, эпизоотии и т. д. Кроме того, в УК РФ введена ст. 207.2, которая предусматривает ответственность за распространение ложной информации, которая повлекла тяжкие последствия. Так же Ф3 № 100 была изложена новая редакция статьи 236 УК РФ. Теперь в данной статье увеличена санкция и дополнена частью о нарушение санитарно-эпидемиологических правил, которые повлекли смерть двух или более лиц [19].

Верховный Суд РФ в Обзоре № 2 разъяснил, что следует понимать под «массовым заболеванием или отравлением людей» либо
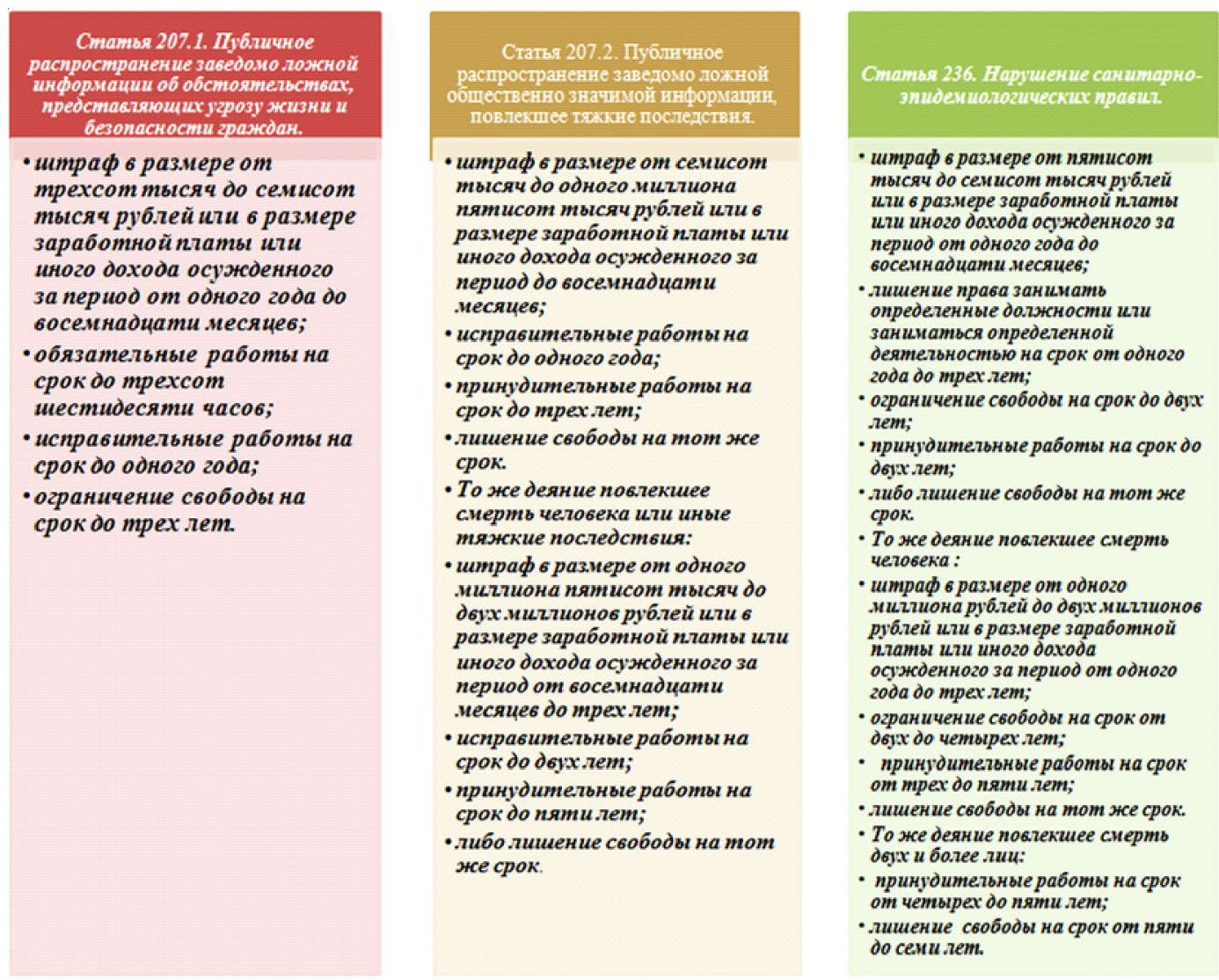

Рис. 3. Ответственность по статьям 207.1 УК РФ, 207.2 УК РФ, 236 УК РФ 
«созданием угрозы наступления таких последствий» [6].

В связи с этим мы критически относимся к предложению М.А. Ефремовой, А.А. Шутовой, А.А. Никифировой, предлагающих исключить из диспозиции ч. 1 ст. 236 УК РФ возможность привлечения к уголовной ответственности за нарушение санитарно-эпидемиологических правил, создавшее угрозу наступления последствий в виде массового заболевания и отравления людей [1, с. 544]. Полагаем, что решение об отнесении деяния к административному правонарушению (ч. 2 или ч. 3 ст. 6.3 КоАП РФ) или же уголовному преступлению, предусмотренному ст. 236 УК РФ, всецело находится в компетенции правоохранительных органов, и как правильно указал Верховный Суд в вышеуказанном обзоре, является оценочным и зависит от тяжести наступивших последствий, то есть разграничение между ними определяется степенью их общественной опасности. Ведь необязательно же нам ждать, когда, например, больной тяжелой формой коронавирусной инфекции, пусть даже по неосторожности, заразит как можно больше людей в крупном гипермаркете, аквапарке и т. д., и только тогда мы будем привлекать его к уголовной ответственности по данной статье? Заметим, что риски, связанные с постепенным снятием ограничений в регионах, как бы мы этого не хотели, будут пока только возрастать.

\section{3. Полиция отвечает на новые вызовы}

В связи с этим появилась необходимость усиления соблюдения изоляции на улицах, в общественных местах. Для этого необходима слаженная работа сотрудников органов внутренних дел. Так, министр внутренних дел Владимир Колокольцев заявил о серьезных коррективах в оперативно-служебной деятельности, призвав подчиненных подойти к реализации плана с максимальной ответственностью.

Контроль над соблюдением режима самоизоляции возложен на сотрудников ОВД. Сотрудники патрульно-постовой службы, заступая в суточный наряд, должны пресекать данные нарушения. Таким образом, в случаях, когда на улицах, спортивных площадках, в парках, скверах и т. д. находится более двух человек, сотрудники обязаны потребовать объяснений, по какой причине нарушено распоряжение о соблюдении режима самоизоляции. Сотрудники обязаны требовать возвращения людей домой, провожать их до места проживания, а в случаях неповиновения законных требований, имеют право составлять протокол в соответствии с КоАП РФ.

Патрулирование происходит в пешем порядке и на машинах. Сотрудники ППСП, а также сотрудники ГИБДД обязаны проверять соответствующие пропуска, выданные той организацией или тем органом, в котором непосредственно осуществляет свою деятельность конкретное лицо. Такие пропуска имеют электронный вариант и содержат определенные реквизиты. Для того чтобы отличать действительный пропуск от поддельного, данные пропуска заносятся в электронную базу, которая доступна сотрудникам полиции. Кроме этого, используется система видеонаблюдения, а также система геолокации лица, для того чтобы пресекать нарушение установленного маршрута.

Как показал анализ вынесенных судами решений по ст. 20.6.1 КоАП РФ с апреля по декабрь 2020 г., в основном суды назначают таким правонарушителям наказание в виде предупреждения или штрафа в размере 13 тысяч рублей [13].

МВД России также был принят ряд нормативных правовых актов в исследуемой сфере. Первый заместитель министра внутренних дел генерал-полковник полиции А.В. Горовой 19 марта 2020 г. подписал требование работы с мигрантами в период распространения пандемии. Данное требование содержит инструкции для сотрудников по работе с документами иностранных граждан в рамках применения дополнительных мер по предупреждению распространения коронавирусной инфекции. Инструкция содержит более упрощенную форму выдачи документа для временно пребывающих иностранных граждан в Российскую Федерацию. К тому же, иностранные лица, кроме получения миграционной карты и продления срока пребывания в Российской Федерации до 90 суток, имеют право оформить патент на работу, не выезжая из страны [12]. 
Вместе с тем у сотрудников полиции возникает ряд трудностей при выполнении своих обязанностей, например, при задержании граждан, нарушивших режим самоизоляции или покинувших без разрешения обсерватор для больных COVID-19. По сути, их действия по исполнению предписаний санитарных врачей и задержанию правонарушителей на законодательном уровне ничем не урегулированы. Поэтому мы также поддерживаем позицию А.В. Равнюшкина о внесении изменений в Федеральный закон «О полиции» и наделении сотрудников соответствующими полномочиями [11, с. 68-69].

В период распространения коронавирусной инфекции уличная преступность уступила место киберпреступлениям. Правоохранительные органы, к сожалению, оказались не готовы бороться с кибермошенниками в новых условиях. Так, преступники действуют в нынешних обстоятельствах более сплоченно, профессионально, грамотно. Это подтверждают и данные официальной статистики. Согласно ГИАЦ МВД Российской Федерации в январе - декабре 2020 г. количество преступлений, совершенных с использованием информационно-телекоммуникационных технологий, возросло на 73,4 \%, в том числе с использованием сети Интернет - на 91,3 \%, при помощи средств мобильной связи - на 88,3 \% [4]. Полиция столкнулась с методами социальной инженерии, которыми играют преступники на эмоциональном состоянии населения страны. Они пытаются выманить реквизиты карт и СМС-пароли, используя в своих убеждениях негативную новостную повестку о пандемии и экономической ситуации. Сотрудникам приходится совершенствовать навыки в данной сфере, чтобы бороться с такой преступностью. Необходима выработка новых способов и методов, а для этого нужно достаточно полно изучить все особенности данного вида преступлений.

\section{Вывод}

Подводя итог сказанному, следует отметить, что мы являемся свидетелями происходящих в последнее время событий в стране, когда резко возросло давление на политические и общественные институты как внутри страны, так и за ее пределами, в том числе с использованием «коронавирусной повестки». Так, сейчас в средствах массовой информации и, в частности, в сети Интернет развернулась широкомасштабная компания по дискредитации российской вакцины от коронавирусной инфекции «Спутник V». Например, только одних результатов введенного авторами по поиску словосочетания «О вреде вакцины спутник» поисковой системой Google было выдано 610 тысяч. На данные действия официальным властям, по нашему мнению, следует адекватно и в правовом плане реагировать, поскольку это уже используется деструктивными силами по дестабилизации политической обстановки в России. Полагаем, что за распространение таких фейковых новостей правоохранительным органам следует привлекать виновных лиц в зависимости от тяжести наступивших последствий к ответственности по ст. 13.15 КоАП РФ или ст. 207.1 УК РФ, ст. 207.2 УК РФ.

K сожалению, распространение COVID19 пока продолжается и санитарно-эпидемиологическая обстановка в стране остается еще очень сложной. На официальном сайте Федеральной службы по надзору в сфере защиты прав потребителей и благополучия человека находятся все эпидемиологические сведения о распространении коронавирусной инфекции [16]. В этой сложной для страны ситуации необходимо направить все силы для борьбы с этим врагом, а для этого нужно активировать не только все министерства и ведомства, но прежде всего самих граждан. Безусловно, министерства здравоохранения и внутренних дел являются главными «защитниками» в борьбе с COVID-19. Но также важно понимание простых граждан о том, что справиться с этим злом одними лишь административными и организационными мерами невозможно. Следует расширять разъяснительную деятельность среди населения о необходимости соблюдения изоляции в случае выявления заболевания, мерах по профилактике коронавирусной инфекции, в том числе положительных сторонах вакцинации от нее и безопасности самих вакцин. И только так можно добиться каких-либо ощутимых успехов в этом направлении. Кроме того, следует безусловно уважать труд и героизм врачей, ко- 
торые сами зачастую погибая, спасают человеческие жизни, леча тяжелобольных ковидом, создавая сутками без сна в лабораториях вакцины, которые смогут его победить, и за это мы все должны быть им безмерно благодарны. Также надо понимать и специфику деятельности правоохранительных органов в современных реалиях, которые также рискуя в общем то собственным здоровьем, а то и жизнью, оберегают граждан от более серьезных последствий, когда задерживают граждан, не соблюдающих санитарно-эпидемиологические предписания. Поэтому, как представляется, надо быть толерантными как по отношению к государству, так и, наверное, прежде всего друг к другу, заботиться о своем здоровье и здоровье близких и окружающих людей.

\section{СПИСОК ЛИТЕРАТУРЫ}

1. Ефремова, М. А. Новеллы уголовного законодательства в условиях пандемии / М. А. Ефремова, А. А. Шутова, А. А. Никифорова // Вестник Удмуртского университета: экономика и право. 2020. - Т. 30, № 4. - С. 541-553.

2. Жителей Москвы и Подмосковья освободили от платы за капремонт из-за коронавируса. Электрон. текстовые дан. - Режим доступа: https:// www.kommersant.ru/doc/4309172 (дата обращения: 15.01.2021). - Загл. с экрана.

3. Карта коронавируса COVID-19 онлайн. Электрон. текстовые дан. - Режим доступа: https:// coronavirus-monitor.info (дата обращения: 15.01.2021). - Загл. с экрана.

4. Краткая характеристика состояния преступности в Российской Федерации за январь - декабрь 2020 года. - Электрон. текстовые дан. - Режим доступа: https://мвд.pф/reports/item/22678184/ (дата обращения: 15.01.2021). - Загл. с экрана.

5. Меры поддержки бизнеса. - Электрон. текстовые дан. - Режим доступа: https://www.nalog.ru/ rn68/business-support-2020 (дата обращения: 25.01.2021). - Загл. с экрана.

6. Обзор по отдельным вопросам судебной практики, связанным с применением законодательства и мер по противодействию распространению на территории Российской Федерации новой коронавирусной инфекции (COVID-19) № 2. - Электрон. текстовые дан. - Режим доступа: http://www. supcourt.ru/press_center/news/28883/(дата обращения: 15.01.2021). - Загл. с экрана.

7. Поддержка безработных. - Электрон. текстовые дан. - Режим доступа: https://стопкорона- вирус.p $\phi /$ what -is-done/social-measures/ podderzhka_bezrabotnyh.html (дата обращения: 15.01.2021). - Загл. с экрана.

8. Постановление Главного государственного санитарного врача РФ от 22 мая 2020 г. № 15 (ред. от 13.11.2020) «Об угверждении санитарно-эпидемиологических правил СП 3.1.3597-20 “Профилактика новой коронавирусной инфекции (COVID-19)"» // Российская газета. - 2020 (29 мая). - № 115.

9. Постановление Правительства РФ от 2 апреля 2020 г. № 420 (ред. от 31.12.2020) «О внесении изменений в Правила предоставления субсидий на оплату жилого помещения и коммунальных услуг и об особенностях предоставления субсидий на оплату жилого помещения и коммунальных услуг» // Собрание законодательства РФ. - 2020 (13 апр.). № 15 (ч. IV). - Ст. 2277.

10. Постановление Правительства РФ от 2 апреля 2020 г. № 409 (ред. от 07.11.2020) «О мерах по обеспечению устойчивого развития экономики» // Собрание законодательства РФ. - 2020 (13 апр.). № 15 (ч. IV). - Ст. 2267.

11. Равнюшкин, А. В. Организационно-правовые проблемы применения сотрудниками полиции законодательства по противодействию распространению новой коронавирусной инфекции (COVID-19) (на примере Республики Крым) / А. В. Равнюшкин // Вестник Уральского юридического институга МВД России. - 2020. - № 4. - С. 63-69.

12. Распоряжение МВД ог 19.03 .2020 г. № $1 / 2964$ «О дополнительных мерах по предупреждению распространения коронавирусной инфекции (2019$\mathrm{nCoV}) \gg$.

13. Судебная практика. Статья 20.6.1. Невыполнение правил поведения при чрезвычайной ситуации или угрозе ее возникновения. - Электрон. текстовые дан. - Режим доступа: https://sudact.ru/law/ koap/razdel-ii/glava-20/statia-20.6.1/ (дата обращения: 15.01.2021). - Загл. с экрана.

14. Уволенные в период пандемии выигрывают первые суды у работодателей. - Электрон. текстовые дан. - Режим доступа: http://rapsinews.ru/ judicial_news/20201106/306475686.html (дата обращения: 15.01.2021). - Загл. с экрана.

15. Указ Президента РФ от 07.04.2020 № 249 (ред. от 11.05.2020) «О дополнительных мерах социальной поддержки семей, имеющих детей» // Собрание законодательства РФ. - 2020 (13 апр.). - № 15 (ч. I). - Ст. 2243.

16. Федеральная служба по надзору в сфере защиты прав потребителей и благополучия человека. - Электрон. текстовые дан. - Режим доступа: https://www.rospotrebnadzor.ru/ (дата обращения: 15.01.2021). - Загл. с экрана.

17. Федеральный закон от 01.04.2020 № 99-Ф3 (ред. от 29.12.2020) «О внесении изменений в Ко- 
декс Российской Федерации об административных правонарушениях» // Российская газета. - 2020 (3 апр.). - № 72 .

18. Федеральный закон от 03.04.2020 № 106-Ф3 «О внесении изменений в Федеральный закон “О Центральном банке Российской Федерации (Банке России)" и отдельные законодательные акты Российской Федерации в части особенностей изменения условий кредитного договора, договора займа» // Российская газета. - 2020 (6 апр.). - № 73.

19. Федеральный закон от 1 апреля 2020 г. № 100-Ф3 «О внесении изменений в Уголовный кодекс Российской Федерации и статьи 31 и 151 Уголовно-процессуального кодекса Российской Федерации» // Российская газета. - 2020 (3 апр.). - № 72.

20. Щелканов, М. Ю. Коронавирусы человека (Nidovirales, Coronaviridae): возросший уровень эпидемической опасности / М. Ю. Щелканов, Л. В. Колобухина, Д. К. Львов // Лечащий врач. 2013. - С. 49-54.

21. Экономика vs вирус: между землей и небом война. - Электрон. текстовые дан. - Режим доступа: https://www.interfax.ru/business/743497 (дата обращения: 15.01.2021). - Загл. с экрана.

\section{REFERENCES}

1. Efremova M.A., Shutova A.A., Nikiforova A.A. Novelly ugolovnogo zakonodatelstva $\mathrm{v}$ usloviyakh pandemii [Novels of criminal legislation in a pandemic]. Vestnik Udmurtskogo universiteta: ekonomika i pravo [Bulletin of the Udmurt University: Economics and Law], 2020, vol. 30, no. 4, pp. 541-553.

2. Zhiteley Moskvy i Podmoskovia osvobodili ot platy za kapremont iz-za koronavirusa [Residents of Moscow and Moscow region were exempted from overhaul fees due to coronavirus]. URL: https:// www.kommersant.ru/doc/4309172.

3. Karta koronavirusa COVID-19 onlayn [Online Coronavirus COVID-19 Map]. URL: https:// coronavirus-monitor.info.

4. Kratkaya kharakteristika sostoyaniya prestupnosti v Rossiyskoy Federatsii za yanvar dekabr 2020 goda [Brief description of the state of crime in the Russian Federation in January - December 2020]. URL: https://мвд.pф/reports/item/22678184/.

5. Mery podderzhki biznesa [Business support measures]. URL: https://www.nalog.ru/rn68/businesssupport-2020/

6. Obzor po otdelnym voprosam sudebnoy praktiki. svyazannym $s$ primeneniyem zakonodatelstva $i$ mer po protivodeystviyu rasprostraneniyu na territorii Rossiyskoy Federatsii novoy koronavirusnoy infektsii (COVID-19) № 2 [Review of selected issues of judicial practice related to the application of legislation and measures to counter the spread of a new coronavirus infection (COVID-19) in the Russian Federation No. 2]. URL: http://www.supcourt.ru/press_center/news/28883/

7. Podderzhka bezrabotnykh [Support for the unemployed]. URL: https:/стопкоронавирус.pф/ what-is-done/social-measures/podderzhka_ bezrabotnyh.html.

8. Postanovleniye Glavnogo gosudarstvennogo sanitarnogo vracha RF ot 22 maya 2020 g. № 15 (red. ot 13.11.2020) «Ob utverzhdenii sanitarnoepidemiologicheskikh pravil SP 3.1.3597-20 «Profilaktika novoy koronavirusnoy infektsii (COVID-19)» [Resolution of the Chief State Sanitary Doctor of the Russian Federation of May 22, 2020 No. 15 "On the approval of sanitary and epidemiological rules of the joint venture 3.1.3597-20" Prevention of new coronavirus infection (COVID-19)"]. Rossiyskaya gazeta [Russian newspaper], 29.05.2020, no. 115.

9. Postanovleniye Pravitelstva RF ot 2 aprelya 2020 g. № 420 (red. ot 31.12.2020) «O vnesenii izmeneniy v Pravila predostavleniya subsidiy na oplatu zhilogo pomeshcheniya i kommunalnykh uslug i ob osobennostyakh predostavleniya subsidiy na oplatu zhilogo pomeshcheniya i kommunalnykh uslug» [Resolution of the Government of the Russian Federation of April 2, 2020 No. 420 "On Amendments to the Rules for Granting Subsidies for Payment of Residential Premises and Utilities and on the Specifics of Granting Subsidies for Payments for Residential Premises and Utilities"]. Sobraniye zakonodatelstva $R F$ [Collection of legislation of the Russian Federation], 13.04.2020, No. 15 (Part IV), Art. 2277.

10. Postanovleniye Pravitelstva RF ot 2 aprelya 2020 g. № 409 (red. ot 07.11.2020) «O merakh po obespecheniyu ustoychivogo razvitiya ekonomiki»» [Resolution of the Government of the Russian Federation of April 2, 2020 No. 409 "On measures to ensure sustainable development of the economy"]. Sobraniye zakonodatelstva $R F$ [Collection of legislation of the Russian Federation], 13.04.2020, no. 15 (part IV), art. 2267.

11. Ravniushkin A.V. Organizatsionnopravovyye problemy primeneniya sotrudnikami politsii zakonodatelstva po protivodeystviyu rasprostraneniyu novoy koronavirusnoy infektsii (COVID-19 ) (na primere Respubliki Krym) [Organizational and legal problems of police officers' application of legislation to counter the spread of a new coronavirus infection (covid-19) (on the example of the Republic of Crimea)]. Vestnik Uralskogo yuridicheskogo instituta MVD Rossii [Bulletin of the Ural Law Institute of the Ministry of Internal Affairs of Russia], 2020, no. 4, pp. 63-69.

12. Rasporyazheniye MVD ot 19.03.2020 g. № 1/2964 «O dopolnitelnykh merakh po 
preduprezhdeniyu rasprostraneniya koronavirusnoy infektsii (2019-nCoV)» [Order of the Ministry of Internal Affairs of 19.03.2020 No. 1/2964 "On additional measures to prevent the spread of coronavirus infection (2019-nCoV)"].

13. Sudebnaya praktika. Statia 20.6.1. Nevypolneniye pravil povedeniya pri chrezvychaynoy situatsii ili ugroze eye vozniknoveniya [Arbitrage practice. Article 20.6.1. Failure to comply with the rules of conduct in an emergency or the threat of its occurrence]. URL: https://sudact.ru/law/koap/razdelii/glava-20/statia-20.6.1.

14. Uvolennyye $v$ period pandemii vyigryvayut pervyye sudy u rabotodateley [Those dismissed during the pandemic win the first courts against employers]. URL: http://rapsinews.ru/judicial_news/20201106/ 306475686.html.

15. Ukaz Prezidenta RF ot 07.04.2020 № 249 (red. ot 11.05.2020) «O dopolnitelnykh merakh sotsialnoy podderzhki semey, imeyushchikh detey» [Decree of the President of the Russian Federation of 07.04.2020 No. 249 "On additional measures of social support for families with children"]. Sobraniye zakonodatelstva $R F$ [Collected Legislation of the Russian Federation], 13.04.2020, no. 15 (part I), art. 2243.

16. Federalnaya sluzhba po nadzoru $v$ sfere zashchity prav potrebiteley $i$ blagopoluchiya cheloveka [Federal Service for Supervision of Consumer Rights Protection and Human Welfare]. URL: https://www.rospotrebnadzor.ru.

17. Federalnyy zakon ot 01.04 .2020 № 99-FZ (red. ot 29.12.2020) «O vnesenii izmeneniy v Kodeks Rossiyskoy Federatsii ob administrativnykh pravonarusheniyakh» [Federal Law dated 01.04.2020 No. 99-FZ "On Amendments to the Code of the
Russian Federation on Administrative Offenses"]. Rossiyskaya gazeta [Russian newspaper], 03.04.2020, no. 72 .

18. Federalnyy zakon ot 03.04.2020 № 106-FZ «O vnesenii izmeneniy v Federalnyy zakon "O Tsentralnom banke Rossiyskoy Federatsii (Banke Rossii)” i otdelnyye zakonodatelnyye akty Rossiyskoy Federatsii v chasti osobennostey izmeneniya usloviy kreditnogo dogovora, dogovora zayma» [Federal Law dated 03.04.2020 No. 106-FZ "On Amendments to the Federal Law" On the Central Bank of the Russian Federation (Bank of Russia) "and certain legislative acts of the Russian Federation regarding the specifics of changing the terms of a credit agreement, loan agreement"]. Rossiyskaya gazeta [Russian newspaper], 06.04.2020, no. 73.

19. Federalnyy zakon ot 1 aprelya 2020 g. № $100-$ FZ «O vnesenii izmeneniy v Ugolovnyy kodeks Rossiyskoy Federatsii i stati 31 i 151 Ugolovnoprotsessualnogo kodeksa Rossiyskoy Federatsii» [Federal Law of April 1, 2020 No. 100-FZ “On Amendments to the Criminal Code of the Russian Federation and Articles 31 and 151 of the Criminal Procedure Code of the Russian Federation"]. Rossiyskaya gazeta [Russian newspaper], 03.04.2020, no. 72 .

20. Shchelkanov M.Yu., Kolobukhina L.V., Lvov D.K. Koronavirusy cheloveka (Nidovirales. Coronaviridae): vozrosshiy uroven epidemicheskoy opasnosti [Human coronaviruses (Nidovirales, Coronaviridae): increased level of epidemic danger]. Lechashchiy vrach [Therapist], 2013, pp. 49-54.

21. Ekonomika vs virus: mezhdu zemley i nebom voyna [Economy vs virus: war between earth and sky]. URL: https://www.interfax.ru/business/743497.

\section{Information About the Authors}

Alexander V. Sarychev, Lecturer, Department of Tactical and Special Training, Belgorod Law Institute of the Ministry of Internal Affairs of Russia named after I.D. Putilin, Gorkogo St, 71, 308024 Belgorod, Russian Federation,w0773@yandex.ru, https://orcid.ord/0000-0002-2115-3191

Ivan N. Arkhiptsev, Candidate of Sciences (Jurisprudence), Associate Professor, Department of Criminal Law Disciplines, Belgorod Law Institute of the Ministry of Internal Affairs of Russia named after I.D. Putilin, Gorkogo St, 71, 308024 Belgorod, Russian Federation, ArhiptsevIN@yandex.ru, https://orcid.ord/0000-0003-2307-2712

Ekaterina A. Karaulova, Cadet, Faculty of Law Enforcement, Belgorod Law Institute of the Ministry of Internal Affairs of Russia named after I.D. Putilin, Gorkogo St, 71, 308024 Belgorod, Russian Federation, karaulova.yekaterina@list.ru, https://orcid.ord/0000-0003-4963-3418 


\section{Информация об авторах}

Александр Викторович Сарычев, преподаватель кафедры тактико-специальной подготовки, Белгородский юридический институт МВД России им. И.Д. Путилина, ул. Горького, 71, 308024 г. Белгород, Российская Федерация, w0773@yandex.ru, https://orcid.org/0000-0002-2115-3191

Иван Николаевич Архипцев, кандидат юридических наук, доцент кафедры уголовно-правовых дисциплин, Белгородский юридический институт МВД России им. И.Д. Путилина, ул. Горького, 71, 308024 г. Белгород, Российская Федерация, ArhiptsevIN@yandex.ru, https://orcid.org/0000-0003-2307-2712

Екатерина Алексеевна Караулова, курсант факультета правоохранительной деятельности, Белгородский юридический институт МВД России им. И.Д. Путилина, ул. Горького, 71, 308024 г. Белгород, Российская Федерация, karaulova.yekaterina@list.ru, https://orcid.org/0000-0003-4963-3418 